Zeszyty Naukowe Szkoły Głównej Gospodarstwa Wiejskiego w Warszawie

Problemy Rolnictwa Światowego tom 18 (XXXIII), zeszyt 1, 2018: 183-193

DOI: $10.22630 /$ PRS.2018.18.1.17

Jakub Piecuch $^{1}$, Joanna Szarek ${ }^{2}$

Uniwersytet Rolniczy im. Hugona Kołłątaja

\title{
Konkurencyjność gospodarki województwa małopolskiego a rozwój ekosystemu startupowego
}

\section{Competitiveness of the Economy of the Małopolska Region and the Development of the Startup Ecosystem}

\begin{abstract}
Synopsis. W XXI wieku konkurencyjna gospodarka regionu jest gospodarką opartą na wiedzy i nowych technologiach. Przedsiębiorstwa typu startup wraz z ekosystemem startupowym stały się wyznacznikiem innowacyjności regionu. Artykuł ma na celu ukazanie zależności pomiędzy rozwojem krakowskiego środowiska startupowego a wzrostem konkurencyjności województwa małopolskiego. Za podstawowe czynniki oddziałujące na konkurencyjność Małopolski uznano liczbę udzielonych patentów na wynalazki krajowe przez Urząd Patentowy RP, dynamikę zatrudnienia w B+R, nakłady inwestycyjne na $\mathrm{B}+\mathrm{R}$, liczbe przedsięiorstw $\mathrm{z}$ kapitałem zagranicznym oraz PKB per capita $\mathrm{W}$ cenach bieżących. Po przeprowadzonej analizie korelacji wykazano, że najsilniejsze zależności zachodzą pomiędzy PKB per capita $\mathrm{w}$ cenach bieżących a liczbą przedsiębiorstw $\mathrm{z}$ kapitałem zagranicznym oraz nakładami inwestycyjnymi na B+R. Główny ośrodek miejski, jakim jest w analizowanym obszarze Kraków, stał się magnesem skupiającym wokół siebie osoby zakładające startupy, budujace innowacyjna gospodarkę oraz całe zaplecze biznesowe. Krakowski ekosystem startupowy ma pozytywny wpływ na konkurencyjność regionu małopolskiego z uwagi na gromadzenie wysoko wykwalifikowanego kapitału społecznego, krajowych $i$ zagranicznych inwestorów, fundacji i instytucji wspierających pomysłodawców w zmaterializowaniu idei, działalności instytucji i administracji publicznej w kierunku współpracy z obszarem nauki i biznesu.

Słowa kluczowe: konkurencyjność, innowacyjność, startup, ekosystem startupowy
\end{abstract}

\begin{abstract}
In the 21st century, a region's competitive economy is an economy based on knowledge and new technologies. Startups with the startup ecosystem have become a determinant of a region's innovation. The article aims to show the dependence between the development of the Krakow startup environment and the increase in the competitiveness of the Malopolska region. The number of patents granted for national inventions by the Patent Office of the Republic of Poland, the dynamics of employment in $R \& D$, capital expenditures on $R \& D$, the number of enterprises with foreign capital and GDP per capita in current prices were considered the basic factors affecting the competitiveness of Malopolska. After the analysis of the correlation, it was shown that the strongest relationships occur between GDP per capita in current prices and the number of enterprises with foreign capital and investment outlays for R\&D. The main city center, which is in the analyzed area of Krakow, has become a magnet for gathering people, creating startups, building an innovative economy and all business facilities. The Krakow startup ecosystem has a positive impact on the competitiveness of the Malopolska region due to the accumulation of highly qualified social capital, domestic and foreign investors, foundations and institutions supporting originators in materializing the idea, activities of institutions and public administration towards cooperation with the science and business area.
\end{abstract}

Keywords: competitiveness, innovation, startup, startup ecosystem

JEL Classification: F63, M13, 018

${ }^{1}$ dr hab., Zakład Ekonomii i Polityki Gospodarczej, Wydział Rolniczo-Ekonomiczny UR w Krakowie, al. Mickiewicza 21,31-120 Kraków, e-mail: j.piecuch@ur.krakow.pl

${ }^{2}$ mgr, Zakład Ekonomii i Polityki Gospodarczej, Wydział Rolniczo-Ekonomiczny UR w Krakowie,

al. Mickiewicza 21,31-120 Kraków, e-mail: jszarek_zeipg@poczta.fm 


\section{Wprowadzenie}

Początek XXI wieku jest wyjątkowym okresem w dziejach gospodarki światowej ze względu na przebiegający w bardzo szybkim tempie postęp technologiczny. Najbardziej rozpoznawalny na całym globie region, będący symbolem rozwoju nowych technologii to Dolina Krzemowa, czyli północna część jednego z amerykańskich stanów. Początki kreacji potęgi tego obszaru sięgają lat 50. ubiegłego stulecia, a jego proces rozwoju przebiegając nieustannie z roku na rok, tworzy gospodarkę cyfrową na świecie. Na północy Kalifornii swoje siedziby ma cała gama przedsiębiorstw, zaczynając od tych, które już są dużymi korporacjami międzynarodowymi, rozpoznawalnymi w najdalszym zakątku świata, na przykład Google, Apple, Microsoft, Intel, eBay, jak również początkujących startupów. Równocześnie Dolina Krzemowa jest strategicznie ważnym regionem dla Stanów Zjednoczonych, a jego rola w kreacji konkurencyjności gospodarki Kalifornii jest niezaprzeczalna. Fundamentem konkurencyjności gospodarki jest wiedza, postęp technologiczny oraz zdolność do ciagłego rozwoju. Na terytorium Polski obszarami skupiającymi pokaźną liczbę przedsiębiorstw, inwestorów i innych instytucji otoczenia biznesu są duże ośrodki miejskie. To wokół nich powstają ekosystemy startupowe. Ekosystem startupowy realnie oddziałuje na budowanie gospodarki opartej na wiedzy. Podmioty funkcjonujące w regionie poprzez organizację spotkań tematycznych, konferencji naukowych, forów dyskusyjnych, wymieniając się wiedzą i doświadczeniem, stają się centrum pomocowym dla osób niedoświadczonych w tworzeniu i prowadzeniu działalności gospodarczej.

Niniejsza praca ma na celu ukazanie współzależności pomiędzy rozwojem ekosystemu startupowego a konkurencyjnością gospodarki regionalnej. Wiodącym obszarem poddanym analizie jest województwo małopolskie $\mathrm{z}$ dominującym ośrodkiem miejskim Kraków. Źródłem danych są raporty krakowskich instytucji otoczenia biznesu oraz baza danych Głównego Urzędu Statystycznego.

\section{Teoretyczne zagadnienia wzrostu konkurencyjności gospodarki}

Zagadnienia odnoszące się do pojęcia, jakim jest konkurencyjność gospodarki, są postrzegane przez pryzmat wielu dziedzin życia gospodarczego. Konkurencyjność gospodarki jest ściśle skorelowana z konkurencyjnością cenową, głównie polegając na komparacji cen krajowych w stosunku do zagranicznych. To podejście jest możliwe do akceptacji w momencie, gdy wzrastająca wydajność pracy ewidentnie przewyższa aprecjację płac, a także w przypadku, gdy zmiany w efektywności produkcji są korzystniejsze niż zmiany cen towarów podlegających wymianie międzynarodowej. Te procesy wpływają na obniżenie cen towarów krajowych, przy jednoczesnym braku spadku dynamiki akumulacji. W momencie, gdy nie zachodzi analizowana prawidłowość, podejście jest określane jako niesłuszne, z uwagi na podtrzymywanie konkurencyjności kosztem niskich płac. Powszechnie łączy się konkurencyjność gospodarki bezpośrednio z rozwojem, na którego czele stoi nie tylko wysoka dynamika, ale także zmiany strukturalne w otwartej gospodarce. Alternatywne podejście to postrzeganie konkurencyjności gospodarki przez zdolność kraju do efektywnego zagospodarowania własnych czynników produkcji, kapitału finansowego i ludzkiego oraz posiadanych technologii (Strzelecki, 2008, s. 48-50). Według Organizacji Współpracy Gospodarczej 
i Rozwoju (OECD) konkurencyjność jest równoznaczna z możliwością konkurencji na arenie międzynarodowej zarówno przedsiębiorstw, branż, przemysłów, poszczególnych regionów i państw oraz ugrupowań quasi - narodowych. Komisja Europejska dostrzega regionalny charakter konkurencyjności przez pryzmat osiagania wysokiego poziomu zatrudnienia oraz dochodów na tle międzynarodowej konkurencji (Hryniewicz, 2006, s. 7476). Regionalne ujęcie konkurencyjności jest składową dwóch elementów, a mianowicie międzyregionalne zróżnicowanie i wielkość rynku. Region konkurencyjny rozumie się jako obszar, na którym poziom wiedzy zasobów ludzkich daje możliwość wyprzedzania potrzeb oraz kreacji nowych kombinacji zasobów rzeczowych, co w efekcie skutkuje wykorzystaniem już istniejących zasobów rzeczowych, a także daje możliwość na zbudowanie przewagi strukturalnej i doprowadzenie do skomercjalizowania regionalnych wytworów (Markowski, 2000, s. 30). Cechami charakterystycznymi dla procesu rozwoju konkurencyjności są: wzrost wydajności pracy, stan zatrudnienia na tle bezrobocia, poziom potencjału gospodarczego, rosnąca dynamika dochodów i znaczący wzrost zasobów przedsiębiorstw (Źółtowski, 2005, s. 10). Powszechnie wyróżnia się cztery elementy oddziałujące na konkurencyjność regionów: zróżnicowanie struktur ekonomicznych na danych obszarze, dostępność komunikacyjna, zaplecze badawczo-naukowe oraz otoczenie około biznesowe (Góralski, Lazarek, 2009, s. 309). Na poziom konkurencyjności gospodarki państwa szczególny wpływ mają przedsiębiorstwa. Ingerencja państwa w toczące się procesy gospodarcze jest niezbędna, szczególnie pod kątem wspierania potencjału eksportowego, kreację norm prawno-finansowych otwartych na potrzeby przedsiębiorców, okresowe sprawowanie pieczy nad najsłabszymi branżami, tworzenie organizacji pomagających $\mathrm{w}$ stymulowaniu procesów rozwoju konkurencyjności firm, inwestycje $\mathrm{w}$ infrastrukturę technologiczno-ekonomiczną. Wyróżnia się sześć poziomów konkurencyjności, tak zwane „6M”:

- poziom „Mikro-mikro” dotyczy towarów i usług;

- poziom „Mikro” odnosi się do sektora przedsiębiorstw;

- poziom „Mezo” oznacza konkurencyjność na poziomie poszczególnych branż i gałęzi, sektorów gospodarki, czy regionów;

- poziom „Makro” to aspekty konkurencyjności w skali kraju

- poziom „Mega” interpretowany jest jako konkurencyjność na skalę międzynarodową,

- poziom „Meta” jest poziomem przyszłości (Borowiecki, Siuta-Tokarska, 2015, s. 52-54).

Pomiaru konkurencyjności gospodarki na danym obszarze dokonuje się za pomocą wielu wskaźników w zależności od kierunku prowadzonych badań. Analizy prowadzone się w zakresie inwestycji, infrastruktury administracyjno-techniczno-społecznej, działalności naukowo-badawczej, czy zasobów środowiska naturalnego. W celu oceny konkurencyjności badanych regionów wykorzystuje się głównie wskaźniki:

- w ramach procesów inwestycyjnych: nakłady i wydatki inwestycyjne przedsiębiorstw krajowych i zagranicznych oraz instytucji państwowych, liczbę przedsiębiorstw $\mathrm{z}$ kapitałem zagranicznym funkcjonująca w regionie, liczbę osób zatrudnionych $\mathrm{w}$ przedsiębiorstwach zagranicznych,

- w obszarze działalności badawczo - naukowej: wartość nakładów na Badania + Rozwój i działalność innowacyjną, liczbę uzyskanych patentów, liczbę osób zatrudnionych w sektorze $\mathrm{B}+\mathrm{R}$, 
- w ramach analizy struktury gospodarczej: wskaźnik struktury środków trwałych, wskaźnik struktury podmiotów gospodarczych, wskaźnik nakładów inwestycyjnych w odniesieniu do poszczególnych sektorów,

- ze względu na uwarunkowania naturalne środowiska: walory turystyczne oraz stan środowiska (Góralski, Lazarek, 2009, s. 309-313).

Konkurencyjna gospodarka to obszar, na którym nieustannie istnieje możliwość kreacji nowych kombinacji strukturalnych, głównie poprzez wykorzystanie kapitału ludzkiego, prowadzące do skomercjalizowania idei. (Huczek, 2016, s. 251-252). Postęp technologiczny oddziałuje na zwiększenie wydajności gospodarczej, konkurencyjności na arenie międzynarodowej, czy modernizację struktur gospodarczych. Wiedza i rozwój technologiczny stał się obecnie wyznacznikiem poziomu rozwoju gospodarczego (Grosse, 2002, s. 30-31). Ponadto w literaturze wskazuje się, że to obecność w regionie instytucji naukowo - badawczych i szkolnictwa wyższego jest kryterium oddziałującym na wysoki poziom konkurencyjności regionów (Czudec, 2010, s. 34-35). Bezdyskusyjnym elementem w podnoszeniu konkurencyjności danego obszaru są startupy. Obecnie ośrodki wokół których gromadzi się najwięcej przedsiębiorstw typu startup zlokalizowane są przy dużych miastach. Jest to spowodowane jedną z głównych cech współczesnych miast, a mianowicie coraz większą rolą komunikacji informacji, zarówno mieszkańców, przedsiębiorców, instytucji publicznych, poprzez przepływ informacji podczas transakcji handlowych, zagospodarowaniu przestrzennym miast, procesach legislacyjno-administracyjnych (Domański, 2007, s. 136-141). Z rozwojem startupów bezpośrednio wiąże się kreacja ekosystemów startupowych. Przed to pojęcie rozumie się region gromadzący instytucje pozarządowe wpierające młodych naukowców, administrację publiczna, aniołów biznesu, inwestorów, fundacje, inkubatory przedsiębiorczości, startupy, które już rozpoczęły działalność gospodarczą oraz inne podmioty wpływające na wzrost liczby startupów.

W pierwszej części analizy korelacji pomiędzy badanymi cechami dokonano doboru zmiennych, które świadczą o poziomie konkurencyjności regionu. Zestaw cech został wyłoniony $\mathrm{z}$ dostępnych danych statystycznych, przy wykorzystaniu kryterium merytorycznego. Elementami składowymi kryterium merytorycznego były cel oraz przedmiot badania, a także przedział czasowy, dla którego przeprowadzono badanie (Paluch, Zuzek, 2017, s. 123). Zmiennymi zakwalifikowanymi do analizy korelacji zostały: $\mathrm{X}_{1}$ - Produkt Krajowy Brutto per capita w cenach bieżących (zł),

$\mathrm{X}_{2}$ - liczba przedsiębiorstw z kapitałem zagranicznym,

$\mathrm{X}_{3}$ - nakłady inwestycyjne na Badania i Rozwój (zł).

Punktem wiodącym do określenia współzależności pomiędzy wybranymi zmiennymi było oszacowanie współczynnika korelacji liniowej Pearsona $r_{x y}$. Wskaźnik ten ukazuje siłę związku prostoliniowego pomiędzy dwoma zmiennymi, przyjmując wartości z przedziału $\{-1 ; 1\}$. Dodatnia wartość współczynnika świadczy o pozytywnej współzależności, a ujemna o zależności negatywnej. O sile współzależności występującej pomiędzy analizowanymi zmiennymi świadczy wartość współczynnika korelacji liniowej, a mianowicie im wartość bliższa jedności, tym zależność jest silniejsza. Najczęściej przyjmuje się, że $r_{x y}<0,3$ - nieważna korelacja; $0,3<r_{x y} \leq 0,5$ - korelacja średnia; $r_{x y}>0,5$ - korelacja wyraźna. Estymację współczynnika korelacji liniowej Pearsona przeprowadzono za pomocą poniższej formuły:

$r_{x y}=\frac{n\left(\sum X Y\right)-\left(\sum X\right)\left(\sum Y\right)}{\sqrt{\left[n \sum X^{2}-\left(\sum X\right)^{2}\right] *\left[n \sum Y^{2}-\left(\sum Y\right)^{2}\right]}}$, 
gdzie

$r_{x y}$ - współczynnik korelacji liniowej Pearsona

$\mathrm{n}$ - liczba elementów zbioru

$\mathrm{X}$ - zmienna objaśniająca

Y - zmienna objaśniana (Chudy - Hyski, 2006, s.138).

Obliczenia zostały przeprowadzone na podstawie danych statystycznych Głównego Urzędu Statystycznego, dostępnych w bazie danych Strateg.

\section{Czynniki konkurencyjności województwa małopolskiego}

Jedną z miar służącą do komparacji konkurencyjności poszczególnych państw jest wskaźnik globalnej konkurencyjności (GCI). GCI określa zdolność państwa do zagwarantowania długookresowego wzrostu gospodarczego. Polska z roku na rok odnotowuje w nieznacznym stopniu wzrost tego wskaźnika. W 2016 roku oscylował na poziomie 4,56 punktów, co spowodowało przesunięcie się Polski o pięć miejsc w górę rankingu na trzydziestą szóstą pozycję pośród stu trzydziestu ośmiu krajów świata.

Tabela 1. Ranking województw w Polsce według regionalnego wskaźnika konkurencyjności (RCI) w 2016 r.

Table 1. Ranking of NUTS regions in Poland according to the regional competitiveness index (RCI) in 2016

\begin{tabular}{l|c}
\hline \multicolumn{1}{c|}{ Województwo } & Pozycja w rankingu \\
\hline dolnośląskie & 4 \\
kujawsko-pomorskie & 14 \\
lubelskie & 9 \\
lubuskie & 11 \\
łódzkie & 6 \\
małopolskie & 3 \\
mazowieckie & 1 \\
opolskie & 13 \\
podkarpackie & 12 \\
podlaskie & 14 \\
pomorskie & 5 \\
śląskie & 2 \\
świętokrzyskie & 8 \\
warmińsko-mazurskie & 15 \\
wielkopolskie & 7 \\
zachodniopomorskie & 10 \\
\hline
\end{tabular}

Źródło: opracowanie własne na podstawie: ec.europa.eu/regional_policy/en/information/maps/regional_ competitiveness.

Województwo małopolskie ze względu na regionalny wskaźnik konkurencyjności (RCI) w roku 2016 zajęło trzecią pozycję za województwem mazowieckim i śląskim w rankingu. W celu zwiększenia konkurencyjności gospodarki poszczególnych województw oraz Polski podjęte zostały działania stworzenia specjalnych stref ekonomicznych (SSE). Nadrzędnym celem kreacji takiego podziału regionalnego jest przyspieszenie tempa wzrostu gospodarczego na poszczególnych obszarach działalności 
gospodarczej państwa. Działaniami podejmowanymi w ramach realizacji powyższego celu są między innymi:

- Zwolnienia z uiszczania podatku dochodowego PIT lub CIT;

- Kompleksowa obsługa inwestorów;

- Obszary inwestycyjne, ujęte w planach zagospodarowania przestrzennego;

- Kreacja inkubatorów technologicznych;

- Poszerzenie bazy powierzchni biurowych i konferencyjnych;

- Tworzenie multimedialnych laboratoriów.

$\mathrm{Na}$ terytorium państwa polskiego wyszczególniono czternaście SSE. Na południu Polski wyróżnione zostały dwie specjalne strefy ekonomiczne: katowicka i krakowska. W obrębie województwa małopolskiego obszarami inwestycyjnymi, należącymi do Krakowskiego Parku Technologicznego są: Andrychów, Bochnia, Bukowno, Chełmek, Chrzanów, Czorsztyn, Dąbrowa Tarnowska, Dobczyce, Gdów, Klucze, Kraków Podgórze, Kraków - Nowa Huta, Kraków - Śródmieście, Limanowa, Niepołomice, Nowy Sącz, Nowy Targ, Oświęcim, Skawina, Słomniki, Sucha Beskidzka, Tarnów, Trzebinia, Tuchów, Wolbrom, Zabierzów, Zakliczyn oraz Zator (Potencjał inwestycyjny..., s. 25-28). Poniższa tabela ukazuje nakłady inwestycyjne w Polsce południowej.

Tabela 2. Nakłady inwestycyjne w SSE katowickiej i krakowskiej w mln złotych w latach 2006-2015

Table 2. Capital expenditures in the Katowice SSE and Krakow SSE in 2006-2015

\begin{tabular}{c|cccccccccc}
\hline Rok & 2006 & 2007 & 2008 & 2009 & 2010 & 2011 & 2012 & 2013 & 2014 & 2015 \\
\hline $\begin{array}{c}\text { Nakłady inwestycyjne } \\
(\text { mln PLN) }\end{array}$ & 2502 & 2107 & 2301 & 2503 & 936 & 1403 & 1451 & 838 & 385 & 2800 \\
\hline
\end{tabular}

Źródło: opracowanie własne na podstawie danych dostępnych w bazie danych strateg.stat.gov.pl.

Po okresie deprecjacji nakładów inwestycyjnych na B+R w latach 2013-2014, w roku 2015 odnotowano znaczne zwiększenie inwestycji. Według GUS udział kapitału zagranicznego zainwestowanego w poszczególnych podmiotach w województwie małopolskim w całkowitej wartości kapitału zagranicznego w Polsce przekroczył 6\% w roku 2016, wykazując w niewielkim stopniu tendencję spadkową na przestrzeni ostatnich lat. W porównaniu do województwa mazowieckiego $(47,4 \%)$, wielkopolskiego $(9,8 \%)$, śląskiego (8,4\%), czy dolnośląskiego $(8,3 \%)$, poziom ulokowanego kapitału zagranicznego w Małopolsce nie jest zadawalający. W celu przeprowadzenia analizy korelacji pomiędzy zmiennymi wpływającymi na poziom konkurencyjności województwa małopolskiego, wykorzystano następujące wartości oszacowane dla województwa małopolskiego: liczba udzielonych patentów na wynalazki krajowe przez Urząd Patentowy RP, dynamika zatrudnienia w sektorze Badania + Rozwój $(B+R)$, nakłady inwestycyjne na $B+R$, liczba przedsiębiorstw $\mathrm{z}$ kapitałem zagranicznym oraz PKB per capita $\mathrm{w}$ cenach bieżących.

Poniższe wykresy ukazują zależności pomiędzy analizowanymi zmiennymi. 
Liczba przedsiębiorstw $z$ kapitałem zagranicznym $=356,17+, 03404$ * PKB per capita $\mathrm{w}$ cenach bieżących Korelacja: $r=, 97673$

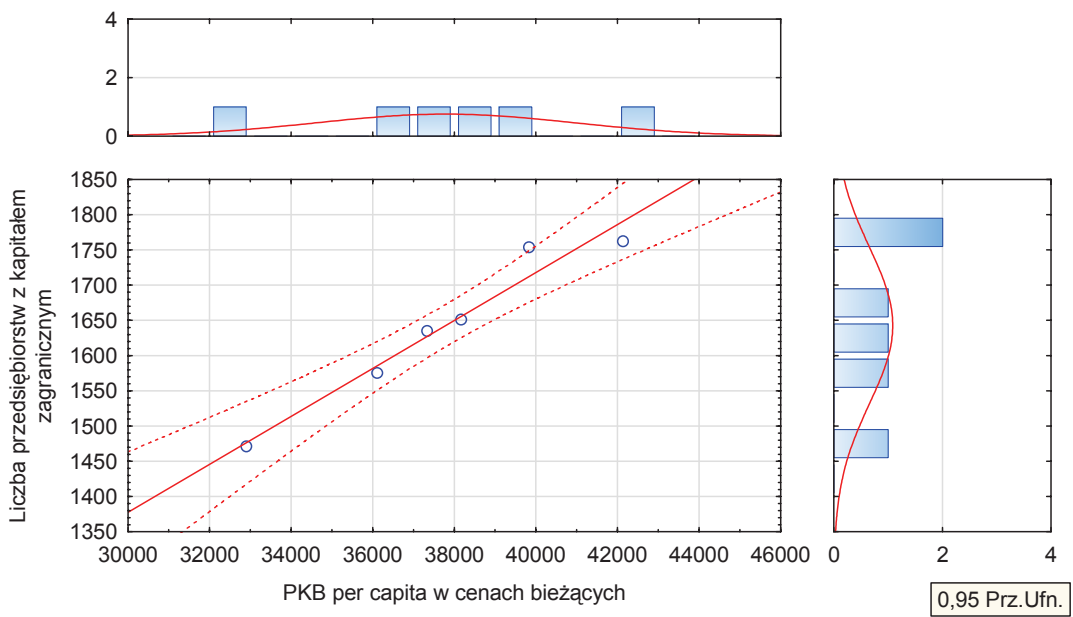

Rys. 1. Wykres rozrzutu: PKB per capita w cenach bieżących vs. liczba przedsiębiorstw z kapitałem zagranicznym Fig. 1. Scatter chart: GDP per capita in current prices vs. number of enterprises with foreign capital Źródło: opracowanie własne.

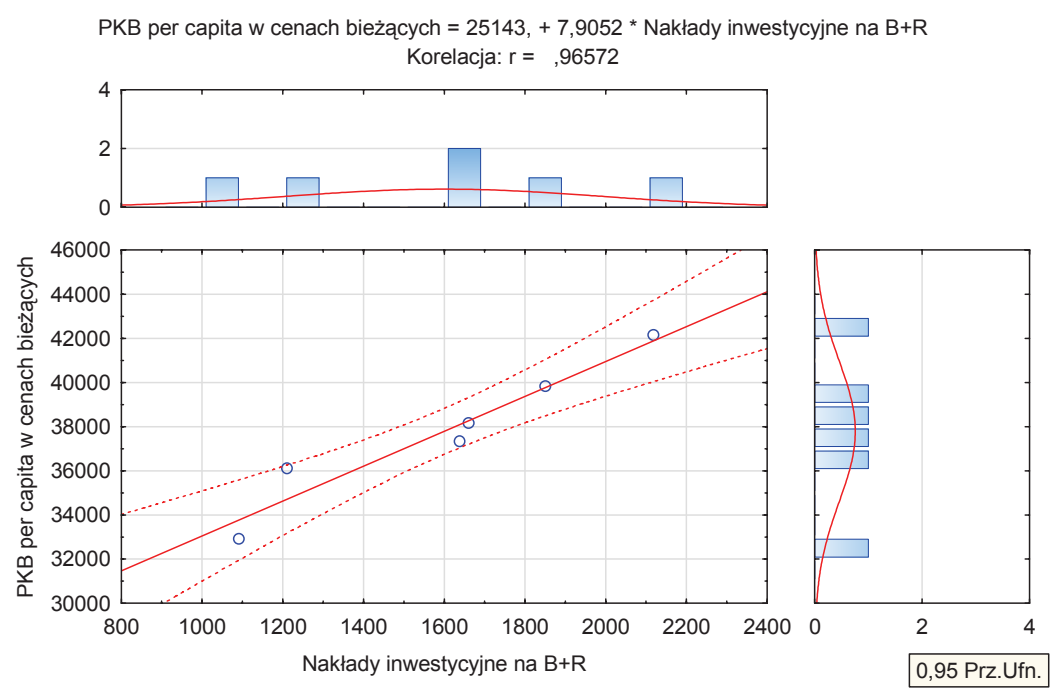

Rys. 2. Wykres rozrzutu: nakłady inwestycyjne na $\mathrm{B}+\mathrm{R}$ vs. PKB per capita w cenach bieżących

Fig. 2. Scatter chart: investment expenditures on R\&D vs. GDP per capita in current prices Źródło: opracowanie własne. 


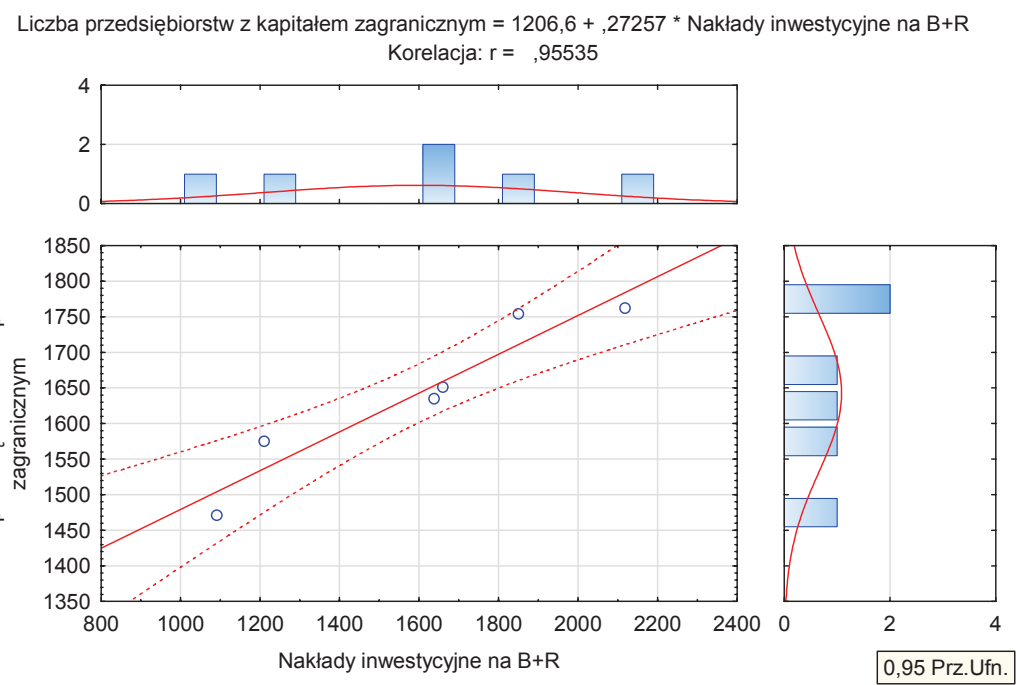

Rys. 3. Wykres rozrzutu: nakłady inwestycyjne na B+R vs. liczba przedsiębiorstw z kapitałem zagranicznym

Fig. 3. Scatter chart: investment expenditures on R\&D vs. number of enterprises with foreign capital

Źródło: opracowanie własne.

We wszystkich analizowanych przypadkach uzyskano zależność liniową dodatnią. Analiza korelacji wykazała najsilniejsze zależności pomiędzy:

- PKB per capita w cenach bieżących a liczbą przedsiębiorstw z kapitałem zagranicznym, przy współczynniku korelacji wynoszącym 0,977;

- nakładami inwestycyjnymi na Badania + Rozwój a PKB per capita w cenach bieżących, gdzie współczynnik korelacji wyniósł 0,966;

- nakładami inwestycyjnymi na Badania + Rozwój a liczbą przedsiębiorstw z kapitałem zagranicznym, ze współczynnikiem korelacji na poziomie 0,955.

W rezultacie dostrzega się zależność, iż wraz ze wzrostem PKB per capita w cenach bieżących wzrasta poziom liczby przedsiębiorstw $\mathrm{z}$ kapitałem zagranicznym. Jest to spowodowane zwiększaniem się poziomu wzrostu gospodarczego oraz pobudzeniem gospodarki, co wpływa korzystnie na postrzeganie badanego regionu, jako korzystnego z punktu widzenia lokowania kapitału. Aprecjacja nakładów inwestycyjnych na badania i rozwój przyczynia się do wzrostu gospodarczego regionu. Z kolei wzrost inwestycji w obszar B\&R jest korzystnie postrzegane przez zagranicznych inwestorów, którzy dostrzegając rozwój naukowo badawczy coraz chętniej inwestują swój kapitał w danych regionie.

\section{Charakterystyka krakowskiego ekosystemu startupowego}

Miasto Kraków jest ważnym punktem na mapie nie tylko województwa małopolskiego, ale również Polski. Uwarunkowania geograficzne, bogactwo kulturowe oraz infrastruktura sprawiaja, że miejsce to jest pełne turystów, studentów, inwestorów, ludzi nauki i biznesu. Rozbudowane miasto jest doskonałym miejscem dla rozwoju przedsiębiorstw typu startup, ze względu na zaplecze badawczo - naukowe i ekonomiczne. Głównie wpływa na to gromadzenie 
w jednym miejscu młodych ludzi rozpoczynających karierę zawodową, posiadających mnóstwo pomysłów oraz osoby wykazujące inicjatywę pomocy w nawiązaniu współpracy z inwestorami, którzy przyczyniają się do zmaterializowania idei. Startupy w głównej mierze skupiają się na dostarczeniu wartości dla potencjalnego klienta, w myśl rozpowszechniającej się ekonomii wartości, a nie na konkurowaniu z funkcjonującymi firmami. Znaczne różnice $\mathrm{w}$ definiowaniu przedsiębiorstw typu startup powoduje rozbieżności w kategoryzowaniu działalności gospodarczej, co wpływa na dysproporcje w oszacowaniu liczby startupów. Według fundacji Startup Poland na terenie województwa małopolskiego działalność gospodarczą prowadzą dziewięćdziesiąt trzy startupy, przy czym osiemdziesiąt osiem funkcjonuje w Krakowie, trzy w Tarnowie i jeden w Alwerni. Inne źródła szacują, że krakowskich podmiotów tego rodzaju jest nawet około trzystu. W Krakowie największy sukces osiagnęło osiem firm: BASE, Brainly, estimote, SILVAIR, kontakt.io, SYNERISE, SALES MANAGO marketing automation oraz ELMODIS. Łącznie podmioty te pozyskały ponad pięćset milionów złotych, zatrudniają około osiemset wysoko wykwalifikowanych pracowników, swoje produkty oferują nie tylko na rynkach krajowych, ale także dystrybuuja je na arenie międzynarodowej. Ich produkty przyczyniają się do rozwoju w zakresie IT, aplikacji mobilnych, sztucznej inteligencji, narzędzi marketingowych, etc (Józefowski, 2017, s. 4-13). Szczegółowy raport odnoszący się do zidentyfikowania struktury krakowskich startupów został przygotowany przez Fundację Kraków Miastem Startupów we współpracy z Urzędem Miasta. W wyniku przeprowadzonych badań ustalono, iż:

- inicjatorzy działalności są osoby głównie osoby w wieku 23-30 lat,

- ponad połowa ankietowanych wskazuje, jako źródło finansowania przedsięwzięć własne środki,

- liczba osób zatrudnionych oscyluje między jedną do trzech osób w przypadku ponad pięćdziesięciu procent respondentów,

- ryzyko działalności w większości przypadków określono jako średnie, jednocześnie wskazując na stosunkowo wysoki lub bardzo wysoki potencjał wzrostu startupu,

- cechami charakterystycznymi dla prowadzonej działalności gospodarczych jest innowacyjność,

- przeważający rodzaj prowadzonej działalności to działalność usługowa,

- nadpłynność finansowa została osiagnięta w ponad siedemdziesięciu procentach podmiotów w latach 2011-2014, jednak aż co drugi startup był nierentowny, a zyski odnotowywane są po dwóch latach prowadzonej działalności (Adamczyk, 2015, s. 11-25).

Ekosystem startupowy to nie tylko podmioty prowadzące działalność gospodarcza, ale instytucje otoczenia biznesu. Startup Poland ujęło czternaście organizacji tworzących krakowski ekosystem startupowy. Sa nimi: \#omgkrk, Ambasada Krakowian, Brainode sp. z o.o., cluster cowork Krakow, COLAB coworking, Django Girls Kraków, Hacktory, Hive 53, Hub:raum Kraków, Innovation Forum Krakow, KrakSpot, KraQA, meet.it, SCKRK. Ponadto ekosystem tworzy wiele fundacji, akceleratorów, inkubatorów przedsiębiorczości, funduszy inwestycyjnych, wspierających rozwój współpracy w sektorze startupowym, takich jak Fundacja Kraków Miastem Startupów, czy Twój Startup oferujący pre-inkubację, rozumianą jako umożliwienie działalności gospodarczej pod opieką innej firmy. Do końca października 2017 roku w ramach nawiązywania kooperacji, poszerzania wiedzy i innowacyjności krakowskiego ekosystemu odbyło się siedemset pięćdziesiąt spotkań. Cieszą się one dużym 
zainteresowaniem, co powoduje, że ich liczba z roku na rok jest coraz większa. W roku 2015 odnotowano ponad czterysta siedemdziesiąt, a w 2016 roku prawie pięćset osiemdziesiąt wydarzeń startupowych (Józefowicz, 2017). Organizowane są zarówno cykliczne spotkania, jak i pojedyncze wydarzenia dla osób planujących zmaterializować swoje projekty, inwestorów szukających lokaty kapitału, naukowców i biznesmenów.

Krakowski ekosystem startupowy oddziałuje na konkurencyjność województwa małopolskiego poprzez:

- tworzenie zaplecza innowacyjnych produktów w różnych sektorach gospodarki przez nieustannie powstające przedsiębiorstwa typu startup;

- rozwój kompetencji kapitału społecznego;

- przyciaganie inwestorów krajowych i zagranicznych, którzy lokują doświadczenie, czas i środki finansowe w niekonwencjonalne pomysły młodych naukowców;

- kreację współpracy osób ze środowiska akademickiego i biznesowego;

- współpracę z instytucjami samorządowymi;

- $\quad$ wzrost zatrudnienia w obszarze $\mathrm{B}+\mathrm{R}$;

- $\quad$ aprecjacja liczby uzyskanych patentów przez przedsiębiorstwa;

- budowanie gospodarki opartej na wiedzy i rozwoju technologicznym.

\section{Podsumowanie}

Pierwsze dwie dekady XXI wieku to czas, gdy dynamicznie postępuje proces transformacji gospodarki materiałochłonnej w kierunku gospodarki opartej na wiedzy. Sprawia to, że kraje, ale także poszczególne regiony konkurują między sobą w obszarze rozwoju nowych technologii. W Polsce dokonano podziałów obszarowych na Specjalne Strefy Ekonomiczne, które mają na celu gromadzenie kapitału inwestycyjnego, mającego budować potencjał technologiczny, ekonomiczny, logistyczny i społeczny. Jednym z takich obszarów na południu Polski jest Krakowska Specjalna Strefa Ekonomiczna. Krakowska SSE przyczynia się do wzrostu potencjału gospodarczego województwa małopolskiego. Jak wynika z przeprowadzonej analizy korelacji, rozwój konkurencyjności województwa małopolskiego dokonuje się w największym stopniu dzięki nakładom inwestycyjnym na badania i rozwój, które przyczyniają się do aprecjacji liczby przedsiębiorstw z kapitałem zagranicznym, lokującym swoje siedziby i inwestycje na tym obszarze, co wynika $z$ przeprowadzonej analizy korelacji. Inwestycje w badania nad nowymi technologiami i rozwojem, zwiększają liczbę osób doskonale wykształconych w branży IT i nanotechnologii, którzy stają się zachętą dla zagranicznych inwestorów i bezpośrednio przekładają się na rosnącą liczbę przedsiębiorstw zagranicznych w Małopolsce. Nieodzownym elementem wzrostu konkurencyjności jest rozwój krakowskiego ekosystemu startupowego. Startupy kreują innowacyjność regionu, budując tym samym jego konkurencyjność. Działalność tego rodzaju firm skutkuje napływem inwestorów i aprecjacją wydatków inwestycyjnych. Władze wojewódzkie prowadzą zakrojone na szeroką skalę działania mające na celu pogłębianie kooperacji otoczenia biznesu i nauki, a co za tym idzie rozbudowę krakowskiego ekosystemu biznesowego. Powstawanie startupów, inwestycje w potencjał naukowo-badawczy i rozwój regionu pozytywnie oddziałuje na podnoszenie poziomu konkurencyjności województwa małopolskiego. 


\section{Literatura}

Adamczyk, M. (2015). Krakowski Ekosystem Startupowy (Cracow Startup Ecosystem). Kraków.

Borowiecki, R., Siuta-Tokarska, B. (2015). Konkurencyjność przedsiębiorstw i konkurencyjność gospodarki Polski - zarys problemu (Competitiveness of enterprises and competitiveness of the Polish economy - an epitome of the problem). Nierówności Społeczne a Wzrost Gospodarczy, 41, 52-66.

Chudy-Hyski D. (2006). Ocena wybranych uwarunkowań rozwoju funkcji turystycznej obszaru. Infrastruktura i ekologia obszarów wiejskich, nr 2/1/2006, Polska Akademia Nauk, Oddział w Krakowie, 129-141

Domański, R. (2007). Gospodarka przestrzenna. Podstawy teoretyczne (Spatial economy. Theoretical basics). PWN, Warszawa.

Górecki, P., Lazarek, M. (2009). Czynniki kształtujące konkurencyjność regionów (Factors Influencing Competitiveness of Regions). ZN SGGW Polityki Europejskie, Finanse i Marketing, 1(50), 307-315.

Grosse, T. (2002). Przegląd koncepcji teoretycznych rozwoju regionalnego (Review of theoretical concepts of regional development). Studia Regionalne i Lokalne, 1(8), 25-48.

Hryniewicz, M. (2006). Konkurencyjność regionów w warunkach integracji Polski z Unią Europejską, Integracja Europejska. Pierwsze doświadczenia (Competitiveness of regions in the conditions of Poland's integration with the European Union, European Integration. First experiences). Białystok.

Huczek, M. (2016). Przedsiębiorczość i konkurencyjność w rozwoju regionalnym (Entrepreneurship and competitiveness in regional development). ZN WSH Zarzadzanie, 3, 247-257.

Józefowicz, B. (2017). Raport: Startupowy Kraków 2017 (Report: Startup Krakow 2017). Kraków.

Markowski, T. (2000). Stymulowanie i regulowanie konkurencyjności w świetle procesów globalizacji gospodarki (Stimulating and regulating the regions' competitiveness in the light of the economic globalization processes). Samorzad Terytorialny, 3, 30-38.

Pająk, K., Dahlke, P., Kvilinskyi, O. (2016). Determinanty rozwoju regionalnego - współczesne odniesienie (Determinants of regional development - a modern reference). Roczniki Ekonomiczne Kujawsko-Pomorskiej Szkoty Wyższej w Bydgoszczy, 9, 109-122.

Paluch Ł., Zuzek D. (2017). Ocena poziomu rozwoju infrastruktury służącej kształtowaniu i ochronie środowiska w województwach Polski (An assessment of level of development infrastructure in the environmental protection in Polish voivodeships). Studia Ekonomiczne. ZN UE w Katowicach, 334, 120-130.

Potencjał inwestycyjny. Specjalne strefy ekonomiczne w Polsce 2016 (Investment potential. Special economic zones in Poland 2016). Colliers International, Warszawa.

Strzelecki, Z. (2008). Gospodarka lokalna i regionalna (Local and regional economy). PWN, Warszawa.

www.ec.europe.eu.

www.stat.gov.pl.

Żółtowski, T. (2005). Ekspertyza dla Ministerstwa Gospodarki i Pracy wykonana w ramach przeprowadzone oceny szacunkowej projektu Narodowego Planu Rozwoju 2007-2013 pt. „Ocena szacunkowa (ex ante) wstępnego projektu Narodowego Planu Rozwoju na lata 2007-2013 w zakresie analizy warunków społeczno-gospodarczych pomocy w kategoriach konkurencyjności gospodarki i innowacyjności przedsiebiorstw" (Expertise for the Ministry of Economy and Labor carried out as part of the assessment of the estimated National Development Plan 2007-2013 project "Estimated (ex ante) assessment of the preliminary draft National Development Plan for 2007-2013 in the scope of analyzing socio-economic conditions of assistance in terms of competitiveness of the economy and innovation of enterprises"). Ministerstwo Gospodarki i Pracy, Departament Koordynacji Polityki Strukturalnej, Warszawa.

Do cytowania / For citation:

Piecuch J., Szarek J. (2018). Konkurencyjność gospodarki województwa małopolskiego a rozwój ekosystemu startupowego. Problemy Rolnictwa Światowego, 18(1), 183-193; DOI: $10.22630 /$ PRS.2018.18.1.17

Piecuch J., Szarek J. (2018). Competitiveness of the Economy of the Małopolska Region and the Development of the Startup Ecosystem (in Polish). Problems of World Agriculture, 18(1), 183-193; DOI: 10.22630/PRS.2018.18.1.17 